УДК 378.018.43:811.111

DOI:

Оксана Савченко, кандидат філологічних наук, викладач кафедри порівняльної педагогіки та методики викладання іноземних мов Дрогобицького державного педагогічного університету імені Івана Франка

\title{
ЦИФРОВІ ТЕХНОЛОГІЇ В ДИСТАНЦЙНОМУ НАВЧАННІ АНГЛІЙСЬКОЇ МОВИ СТУДЕНТІВ ЗВО
}

Стаття присвячена проблемі якісної організації масового онлайн-навчання за допомогою ичифрових освітніх інструментів та ресурсів з метою формування іншомовної комунікативної компетенції у здобувачів вищої освіти мовних спеціальностей. 3 'ясовано, щчо дистанційне навчання іноземної мови в умовах карантину має свої переваги та недоліки. Проте чинні ичифрові платформи, зокрема Zоoт та Google-classroom, месенджери Viber ma Skyре дають можливість організувати як синхронні, так і асинхронні режими навчання, роблять ичей формат навчання пізнавальним, гнучким та інтерактивним. Застосування проаналізованих матеріалів міжнародних освітніх сайтів та відеороликів Үои Тиье надає змогу забезпечити гармонійний розвиток у студентів усіх мовно-мовленнєвих компетентностей, підвищити мотивацію до навчання, розширити світогляд, сформувати сочіокультурні знання, вміння і навички.

Ключові слова: дистанційне навчання; ицфрові технологї; Інтернет-ресурси; аудіо- та відеоподкасти. Jim. 7.

Oksana Savchenko, Ph.D.(Linguistics), Lecturer of the Comparative Pedagogy and Methodology of Teaching Foreign Languages Department Drohobych Ivan Franko State Pedagogical University

\section{DIGITAL TECHNOLOGIES IN STUDENTS' DISTANCE ENGLISH LANGUAGE TEACHING AT INSTITUTIONS OF HIGHER EDUCATION}

The article is devoted to the problem of high-quality organization of mass online learning with the help of digital educational tools and resources in order to form foreign language communicative competence in applicants for higher education in language specialties. It has been found that distance learning of a foreign language in quarantine has its advantages such as a greater opportunity for the use of various authentic educational and methodological materials and improvement of phonological and listening comprehension skills, quick access to information, favourable conditions for applying innovative techniques, retention of larger scope of information, the ability to vary pleasure-reading classes with the help of audiobooks available online etc. However, it is not deprived of negative features. It has been revealed that the existing digital platforms, such as Zoom and Google-classroom, Viber and Skype messengers allow you to organize both synchronous and asynchronous learning modes, making this learning format cognitive, flexible and interactive. The use of analyzed materials of international educational sites and You Tube videos allows to ensure the harmonious development of students of all language and speech competences, increase motivation to studying, expand the worldview, form sociocultural knowledge, skills and abilities. The article also highlights methodological recommendations as to the use of digital technologies during the process of distance learning of the English language, namely: maximum correspondence to traditional lessons; advance and thorough preparation for each online lesson; more emphasis on creative tasks over reproductive activities; the preference of demonstration of You Tube videos with installed rather than automatic subtitles; the selection of videos based on the criteria of language normativity, their content, the relevance to the studied theme; occasionally choose paper resources with the aim of reducing visual load etc.

Keywords: distance teaching; digital technologies; Internet-resources; audio and video podcasts.

$\Pi$ Гостановка проблеми. Дистанційне навчання увійшло в життя суспільства, зокрема і в освітню систему, так несподівано, як і, власне, пандемія коронавірусу. І тому постала вимога різкої зміни підходів навчання, нової організації взаємодії студента та викладача, студентів між собою, і навіть частково критеріїв оцінювання. За півтора року проведення навчання у дистанційній формі, безсумнівно, ще рано говорити про ідеальну модель онлайнзаняття $з$ англійської мови, успішний алгоритм його планування та проведення, оскільки кожен викладач експериментально, методом "проб і помилок" випробовує різні методики та підбирає для себе і своїх студентів оптимальні види, методи і форми навчальної діяльності, зважаючи на різні позалінгвальні чинники, які не мали місця в традиційному аудиторному навчанні. Тому важливим є пошук й аналіз ефективних інструментів для організації масових занять онлайн. У цьому дослідженні йтиметься мова про власний невеликий досвід викладання іноземної мови в умовах віддаленого навчання.

Аналіз останніх досліджень. В освітньому 
просторі проблема застосування цифрових технологій, особливо під час дистанційного навчання, потребує додаткових досліджень та ретельного аналізу. Можливості застосування цифрових технологій у навчанні іноземної мови досліджують такі українські науковці як: А. Гуржій [1], В. Краснопольський [2], Л. Морська[3], О. Овчарук [4], А. Черненко [6] та інші.

Мета статті - аналіз сучасних цифрових технологій та Інтернет-ресурсів, які застосовується у дистанційному навчанні англійської мови студентів 3ВО; визначення переваг і недоліків онлайн-навчання іноземних мов; окреслення загальнонавчальних і методичних рекомендацій щодо оптимізації зазначеної форми навчальної діяльності.

Виклад основного матеріалу. У свій час застосування комп'ютерних навчальних програм внесло неабиякі корективи у процес викладання іноземних мов, його комп'ютеризацію. Подальший розвиток технологій - поява Інтернетмережі і доступ до неї - привів до тотальних змін у навчанні іноземних мов, адже з'явилися нові можливості та ресурси, яких досі не було. Ще в 1997 р. американський методисти М. Уоршауер та П. Ф. Уіттекер назвали основні причини для застосування Інтернету в іншомовній підготовці студентів:

1) сприяє вивченню мови завдяки мовній природі комунікації онлайн. Встановлено, що електронний дискурс складніший в лексичному та синтаксичному аспектах, аніж усний дискурс;

2) забезпечує оптимальні умови для навчання письма завдяки створенню автентичної аудиторії 3 користувачів сайту для письмового спілкування;

3) підвищує мотивацію студентів до навчання;

4) навички користування Інтернетом - запорука професійного зростання, адже вивчення англійської мови через мережу допомагає також опанувати ефективні методи роботи в Інтернеті $[7,27]$.

На сьогоднішній день важливість застосування цифрових технологій у формуванні іншомовної компетентності є беззаперечною і визнається більшістю провідних українських та іноземних методистів. На думку Р. Потапової, впровадження цифрових технологій у практику викладання іноземних мов може розв'язати низку важливих проблем навчального процесу, зокрема скоротити часовий розрив між знайомством 3 новими явищами і контролем результатів, подолати проблему недостатньої диференційованості навчання, врахування індивідуальних особливостей студентів та учнів, налагодити процес цілеспрямованого навчання студентів та учнів прийомів самостійної роботи [5, 54].
Отож, як Інтернет, так і загалом цифрові технології відкривають нові можливості для комунікації та ефективної взаємодії в освітньому середовищі, $є$ невичерпним джерелом інформації $\mathrm{i}$, як показує практика, стають у нагоді в часи, коли традиційне аудиторне навчання $\epsilon$ неможливим.

Освітня діяльність на час карантину здійснюється викладачами нашої кафедри в основному за допомогою інтернет-платформи Zoom, яка надає можливість проводити заняття 3 англійської мови у відеоформаті та онлайн-режимі. Завдяки широкому спектру вбудованих функцій Zoom демонструє високу ефективність у здійсненні навчального процесу з іноземної мови. 3 огляду на частотність використання, найкориснішими функціями, зокрема, є: чат, онлайн-дошка, демонстрація екрану, сесійні зали. До прикладу, інструмент “Демонстрація екрану” дає змогу прослуховувати аудіо, переглядати відео, ілюстрації, презентації, інтерактивні завдання, текстові файли в синхронному режимі, а також при потребі ставити демонстрацію на паузу. “Сесійні зали” уможливлює роботу в парах і групах, приміром, при необхідності складання діалогів, проведенні дискусій, роботі над проєктами тощо. Для цього викладач розподіляє учасників конференції по залах і при потребі переключається між сеансами 3 метою надання інструкцій, внесення коректив у хід роботи, виправлення мовних і мовленнєвих помилок студентів. Сдиним помітним недоліком цього сервісу є обмеження часу відеоконференції.

Іншими комунікаційними сервісами, які активно використовуються у дистанційному навчанні іноземної мови, є Skype та Viber. За допомогою цих месенджерів можна швидко відправляти домашнє завдання у вигляді як текстових файлів, так і мультимедійних, а також посилання на певні Інтернет-ресурси. Окрім того, зручною є можливість у Viber листуватися зі студентами та надавати їм потрібні консультації, уточнення, створивши з цією метою Viber-групу. Таке позаудиторне текстове спілкування має не лише практичні цілі, але й психологічні, оскільки неформальне спілкування поліпшує моральний стан студента, що особливо актуально в теперішній період соціальної ізоляції; дає можливість зняти певну напругу у спілкуванні студентів $з$ викладачами чи між студентами загалом. У цих Viber-групах для створення позитивного емоційного настрою студенти можуть ділитися пізнавальними Інтернетзнахідками, викладач також може відправляти посилання на якісні та нові навчальні матеріали, 


\section{ЦИФРОВІ ТЕХНОЛОГЇ̈ В ДИСТАНЦІЙНОМУ НАВЧАННІ АНГЛІЙСЬКОЇ МОВИ СТУДЕНТІВ ЗВО}

зокрема й на автентичні. До прикладу, можна ділитися актуальними новинами, жартами, відеокліпами, фрагментами з серіалів, художніх та документальних фільмів, телепередач, відеоблогами, дотичними до розмовної теми, яка вивчається, тобто тими Інтернет-ресурсами, на опрацювання яких недостатньо часу на занятті $і$ які мають позитивний ефект у посиленні мотивації до вивчення іноземної мови. Важливо зазначити, що вести листування зі студентами у Viberспільноті слід англійською, що дозволяє додатково повправлятися в розмовному варіанті англійської мови, вживаючи сленг, різноманітні скорочення, характерні для Інтернет-спілкування.

Ще одна не менш важлива платформа для навчання $\epsilon$ Google-classroom. Ï̈̈ основне призначення - створення та оцінювання робіт для виконання як безпосередньо на занятті (тестів, підсумкових робіт), так і перевірка домашнього завдання. Позитивними характеристиками цієї платформи є: зручна організація роботи; можливість долучення до завдання різних текстових, аудіо- та відеоматеріалів (файлів 3 цифрового носія, Google Drive, відео з You Tube); функція коментування, якою можна скористатись при перевірці завдань; можливість відслідковувати призначені, виконані та перевірені роботи; збереження даних Google Classroom на Google диску як викладача, так і студента; виділення конкретного часу на виконання певного тесту в онлайн режимі (12.30) чи дати - на домашнє завдання (22.04.2021); автоматично налаштована 100-бальна система може бути замінена 5-ти чи 12-бальною чи будь-якою іншою; результати перевірених робіт студенти отримують миттєво на електронну пошту, натиснувши на опцію “Повернути роботи”. Отже, ця платформа $\epsilon$ найбільш оптимальною для проведення та оцінювання робіт (тестів, самостійних, контрольних тощо) як у синхронному режимі, так і в асинхронному (домашнє завдання), у вигідний для студента час, а тому робить вивчення іноземної мови максимально гнучким, а оцінювання - достатньо об'єктивним.

Проведений аналіз наявних ресурсів мережі Інтернет і подальше їхнє застосування у власній педагогічній діяльності дозволяє рекомендувати деякі навчальні онлайн-ресурси:

Веб-сайт British Council Learn English (https:// learnenglish.britishcouncil.org/) від Британської ради, яка пропагує британську культуру і сприяє вивченню англійської мови у світі, пропонує вправи для вдосконалення усіх видів мовної та мовленнєвої діяльності: фонетики, лексики, граматики, читання, аудіювання, письма й говоріння. Завдання розподілені за рівнями володіння англійською - від Elementary до Advanced. На сайті також $є$ велика добірка аудіо та відеоматеріалів, журнальних статей на актуальну тематику 3 розробленими до них завданнями у формі роздаткового матеріалу (worksheets) та можливістю коментувати зміст обраного тексту, аудіо чи відео у форумі для обговорення.

British Council Learn English Teens (https:// learnenglishteens.britishcouncil.org/), окрім вправ для практики усіх аспектів мови, містить веселе відео, ігри, вікторини, велику кількість країнознавчого матеріалу, поради для здачі іспитів на перевірку рівня сформованості усіх мовномовленнєвих вмінь та навичок. Цікавою є рубрика “Журнал”, в якій розміщуються статті користувачів сайту в публіцистичому стилі, їхні роздуми на довільну, але актуальну тему соціального, культурного чи науково-технічного характеру.

Ще один ресурс від Британської ради під назвою TeachingEnglish(https://www.teachingenglish.org.uk) охоплює найрізноманітніший навчальнометодичний матеріал для професійного розвитку вчителя та викладача англійської мови: електронні методичні посібники, методичні рекомендації, нові дослідження з методики викладання англійської мови, розробки уроків, вебінари, конференції, семінари, творчі, інтерактивні завдання, впорядковані за віковим принципом, а також безкоштовні онлайн курси.

Доцільним у застосуванні у викладацькій практиці є матеріали веб-сайту News in Levels (https://www.newsinlevels.com). Він містить міжнародні новини в текстовому, аудіо- та відеоформатах. Новини оновлюються щодня і адаптовані до трьох рівнів володіння англійською. Наявний також список корисної лексики. Третій рівень (advanced) демонструє оригінальну відеоверсію новини.

Randal's ESL Cyber Listening Lab (https:// www.esl-lab.com/) - цікавий авторський портал призначений не лише для розвитку вмінь аудіювання, але й активізації діяльності студентів на занятті. Тут можна знайти лексичні ігри, вікторини, інтерактивні завдання, короткі тематичні відеоролики за участю творця сайту. Аудіоподкасти супроводжуються новою лексикою до аудіо, транскриптом, лексичним завданням на закріплення нової лексики, а також тестом множинного вибору на розуміння прослуханого тексту, після виконання якого автоматично видається результат 3 коментарем до обраних відповідей. Аудіювання тексту проводиться 
відповідно до загальноприйнятих методичних рекоменлацій: - у три його етапи: дотекстовий, етап прослуховування та післятекстовий. Останній етап охоплює питання для формування усномовленнєвих навичок на понадфразовому рівні та пошуково-дослідницькі завдання онлайн.

На сайті Eslprintables.com педагоги обмінюються навчальним контентом, зокрема роздатковим дидактичним та наочним матеріалом (схеми, малюнки, таблиці, плакати, презентації). Пошук відповідного розробленого завдання можна здійснювати за віком, складністю, видом мовної чи мовленнєвої діяльності, формою роботи тощо.

Busy teacher (https://busyteacher.org/) має один 3 найбільших репозитаріїв розроблених уроків та їх фрагментів, класифікованих за рівнями складності та мовно-мовленнєвими компетентностями, формування яких вони передбачають.

На основі власного досвіду виокремлюємо також переваги дистанційного онлайн-навчання іноземної мови:

- ширша можливість застосування різноманітних автентичних навчально-методичних веб-ресурсів: текстових документів, текстових і мультимедійних презентацій, аудіо- та відеоподкастів, зокрема Youtube роликів; матеріалів авторитетних міжнародних освітніх сайтів (British Council, BBC Learning English) та інформаційно-розважальних, приміром, система пошуку Үаһоo, яка регулярно оновлює публікації на різну тематику, мова яких сучасна, колоритна, наповнена різними фразовими дієсловами, вільними словосполученнями, ідіомами. Цікавим є додаток із аудіоподкастами під назвою 6 Minute English, який постійно оновлює свою базу новими навчальними аудіоподкастами 3 тайпскриптами, незнайомою лексикою та розробленими до них завданнями. На інтернетплатформі You Tube є багато якісного контенту, який також можна інтегрувати в навчальний процес. Це - відеоматеріали англомовних блогерів, які $є$ переважно носіями мови; пізнавально-освітні You Tube канали, які пропонують короткі відеофрагменти з цікавими дослідженнями та фактами про різні сфери життя, мотиваційними відео й порадами (Bright Side, Bestie);

- швидкий доступ до інформації, коли потрібно звірити значення, вимову чи переклад слова в будь-якому онлайн-словнику; відшукати відомості 3 різних галузей знань в онлайненциклопедії "Вікіпедія" та інших авторитетних довідкових онлайн-виданнях;

- дистанційне навчання дає змогу максимально вдосконалити фонологічну й аудитивну компетентності, оскільки студенти мають можливість майже безперебійно слухати живу англійську мову як безпосередньо на занятті, так і поза ним;

- завдяки постійному доступу до інтернетресурсів і їхньому активному використанню студенти засвоюють значно більший обсяг інформації, аніж при очному навчанні, відповідно продуктивніше взаємодіють між собою, ефективніше вдосконалюють комунікативні та соціокультурні знання, навички та вміння;

- завдяки цифровим технологіям як студенти, так і викладач мають більш сприятливі умови для застосування таких інноваційних технологій, як вебквест, проєктна робота, кейс-метод, дискусія, дебати тощо;

- викладачі мають змогу урізноманітнити й оптимізувати пари 3 домашнього читання, використовуючи аудіокниги, які є у вільному доступі в YouTube та мають синхронний графічний супровід, якісне озвучення і адаптовані до різних рівнів володіння англійської (Learn English through Story, Boston English Center);

- розвиток медіаграмотності, вмінь працювати 3 інформаційно-комунікативною технікою, висловлюватись і спілкуватись за допомогою цих медіазасобів, критично тлумачити інформацію.

Поряд з позитивними рисами онлайн-навчання виділяємо і негативні:

- технічні перебої в роботі Інтернет-мережі (інколи й самої комп'ютерної техніки), які часто трапляються у віддалених гірських регіонах, при поганих погодних умовах; відсутність у деяких студентів комп'ютерів чи планшетів, наявність лише смартфонів, які не є оптимальними для повноцінного використання програми Zoom;

- неякісне технічне забезпечення окремих студентів (наявність лише смартфонів, які не дозволяють використовувати повний функціонал платформи Zoom);

- неможливість контролювання ходу та прозорості виконання особливо письмових завдань, що відображається на об'єктивності оцінювання;

- зорове навантаження як для студента, так i викладача;

- більший інформаційний потік, ніж при офлайннавчанні, а звідси - можливе розумове перенавантаження учасників освітнього процесу.

Пропонуємо певні рекомендації для більш успішного проведення дистанційних занять 3 використанням цифрових технологій :

- заняття має бути максимально наближене до традиційного уроку (структура, цілі, методи, прийоми та форми роботи);

- заняття мають бути змістовні, доступні та цікаві; 
- викладачеві слід ретельно готуватися до заняття, добираючи необхідний навчальний матеріал, опрацьовуючи його, розробляючи завдання, тим більше, що автентичні мультимедійні ресурси не пропонують готових завдань до них і $є$ достатньо складними для розуміння.

- пропоновані завдання мають бути не лише репродуктивно-тренувальними, але й творчими, що стимулює їхній пізнавальний інтерес, пошукову діяльність, активізує творчий потенціал та дає змогу викладачеві більш об'єктивно їх оцінити, адже під час виконання таких завдань (написання есе, листа, підготовка презентації, проєкту, усного висловлювання власної думки, складання діалогів, полілогів, зйомку власного відеоролика тощо) мінімізується ризик і ступінь списування; 3 цією ж метою викладач може заохочувати студентів дописувати в коментарях до статті, відеоблогу.

- для проведення аудіювання слід обирати відеоролики 3 вбудованими субтитрами, а не автоматично відтворюваними, які містять значну кількість орфографічних та лексичних помилок;

- критично відбирати відеоролики, зважаючи на нормативність мовлення блогера, змістову наповненість, дотичність до теми, яка вивчається, і навіть візуальну естетику;

- з метою зменшення зорового навантаження доцільно давати більше завдань 3 наявних у студентів паперових підручників та книжок;

- володіння базовими вміннями таймменеджменту як викладачем для раціонального розподілу часу на різні види діяльності на занятті, так і студентом для успішного виконання домашнього завдання.

- не перевантажувати студентів завданнями;

- чітко формулювати завдання, при необхідності надаючи консультації в чаті групи чи у будь-який інший зручний для студентів та викладача спосіб.

Отже, дистанційне онлайн-навчання є гідною альтернативою очного навчання, особливо в теперішніх непростих умовах - в час коронавірусної епідемії, яке уможливлює успішне проведення навчального процесу, зокрема вивчення іноземної мови студентами 3ВО, хоч і не позбавлене низки недоліків та потребує подальших пошуків шляхів його вдосконалення. Розглянуті цифрові технології та Інтенет-ресурси надають змогу викладачам 3ВО цікаво та доступно подавати новий навчальний матеріал, а студентам - ефективно засвоювати його у власному темпі та зручному для них часі.

Подальших досліджень потребують проблеми створення та обгрунтування методик застосування цифрових технологій, окреслення шляхів та етапів роботи з Інернет-ресурсами на заняттях англійської мови у закладах вищої освіти.

\section{ЛІТЕРАТУРА}

1. Гуржій А. М., Лапінський В. В. Електронні освітні ресурси - від теорії до практики. Сучасні інформаційні технології та інноваційні методики навчання у підготовці фахівців: методологія, теорія, досвід, проблеми. Збірник наукових працьь. Вінниц. держ. пед. ун-т ім. М. Коцюбинського. Київ-Вінниця, 2014. Вип. 38. C. $3-11$.

2. Краснопольський В. Е. Іншомовна підготовка студентів нефілологічних спеціальностей на основі створенні і викоритсання web-технологій: дис. ... д-ра пед. наук : 13.00.01. Східноукраїнський національний університет. Київ. 2019. 438 с.

3. Морська Л. І. Особливості організації та проведення уроку іноземної мови з використанням інформаційних технологій. Наукові записки Національного університету "Острозька академія”. Серія “Філологічна”. 2012. Вип. 25. C. 211-213.

4. Овчарук О. В. Цифрова педагогіка в підготовці вчителя XXI ст. Цифрова компетентність сучасного вчителя нової української школи: зб. тез доповідей учасників Всеукр. наук.-практ. семінару. Київ: ІІТЗН НАПН України, 2018. С. 50-53.

5. Потапова Р. К. Новые информационные технологии и лингвистика: учеб. пособие. Москва. $2016,364 \mathrm{c}$.

6. Черненко А.В. Цифрові технології у процесі навчання майбутніх учителів іноземних мов. Збірник наукових працьь “Педагогіка та психологія”. Харків. 2019. Вип. 61. С.193-200.

7. Warschauer M. The Internet for English Teaching: Guidelines for Teachers. TESL Reporter. 1997. Vol. 30(1). pp. 27-33.

\section{REFERENCES}

1. Hurzhii, A. M. \& Lapinskyi, V. V. (2014). Elektronni osvitni resursy - vid teorii do praktyky [Elearning resources - from theory to practice]. Modern informational technologies and innovative methods in professional training: methodology, theory, experience, problems. Collection of Scientific Papers. Vinnytsia, Vol. 38, pp. 3-11. [in Ukrainian].

2. Krasnopolskyi, V.E. (2019). Inshomovna pidhotovka studentiv nefilolohichnykh spetsialnostei na osnovi stvorenni i vykorytsannia web-tekhnolohii [Foreign language training of students of nonphilological specialties based on creation and use of Web technologies.]. Doctor's thesis. East Ukrainian National University. Kyiv, 438 p. [in Ukrainian]. 
3. Morska, L. I. (2012). Osoblyvosti orhanizatsii ta provedennia uroku inozemnoi movy $\mathrm{z}$ vykorystanniam informatsiinykh tekhnolohii [Organizational and methodical aspects of information technology use at a foreign language lesson]. Scientific papers of the National University "Ostroh Academy". Philology series. Vol. 25, pp. 211-213. [in Ukrainian].

4. Ovcharuk, O. V. (2018). Tsyfrova pedahohika $\mathrm{v}$ pidhotovtsi vchytelia XXI stolittia [Digital pedagogy in $21^{\text {st }}$ century teacher training]. Digital competence of a modern teacher of a new Ukrainian school. Abstracts of papers of all-Ukrainian Scientific and Practical Seminar. Kyiv, pp. 54-56. [in Ukrainian].
5. Potapova, R. (2016). Novye informacionnye tehnologii i lingvistika: ucheb. posobie [New information technologies and linguistics]. Moscow, 364 p. [in Russian].

6. Chernenko, A.V (2019). Tsyfrovi tekhnolohii u protsesi navchannia maibutnikh uchyteliv inozemnykh mov. [Digital Technologies in the Process of Teaching Future Foreign Languages Teachers]. "Pedagogy and psychology". Scientific journal, Kharkiv, Vol. 61. pp. 193-200. [in Ukrainian].

7. Warschauer, M. (1997). The Internet for English Teaching: Guidelines for Teachers. TESL Reporter. No. 30(1), pp. 27-33. [in English].

Стаття надійшла до редакції 16.08.2021

УДК 37.091.12:005.336.2:349:377.36

DOI:

Роман Курок, кандидат юридичних наук, доцент, молодший науковий співробітник лабораторії науково-методичного супроводу підготовки фахівців у коледжах і технікумах Інституту професійно-технічної освіти

Національної академії педагогічних наук Украӥни

\section{ВИКОРИСТАННЯ ІННОВАЦЙНИХ ТЕХНОЛОГІЙ ДЛЯ РОЗВИТКУ ПРАВОВОЇ КОМПЕТЕНТНОСТІ ПЕДАГОГІЧНИХ ПРАЦІВНИКІВ ЕКОНОМІЧНИХ КОЛЕДЖІВ}

У статті обтрунтовано сукупність інноваційних технологій, які доиільно використовувати в системі освіти дорослих для розвитку правової компетентності педагогічних прачівників економічних коледжів. Серед сукупності інноваційних технологій, щуо можуть сприяти досягненню поставленої мети, виокремлюємо технологї̈ проєктного та проблемного навчання, коучингову та кейс-технологї. Вони можуть використовуватися в системі післядипломної освіти як під час безпосереднього проходження підвищення кваліфікації та стажування, так і в міжкурсовий період.

Ключові слова: інновація; інноваційні технологї̈; технологія проєктного навчання; технологія проблемного навчання; коучингова технологія; кейс-технологія.

Jim. 9.

Roman Kurok, Ph.D.(Law Studies), Associate Professor, Junior Researcher of Laboratory of Scientific and Methodological Support of Specialist Training in Colleges and Technical Schools, Institute of Vocational Education and Training

National Academy of Pedagogical Sciences of Ukraine

\section{USING INNOVATIVE TECHNOLOGIES FOR DEVELOPING LEGAL COMPETENCE OF ECONOMIC COLLEGES'TEACHING STAFF}

The article substantiates the set of innovative technologies that should be used in the system of adult education for developing legal competence of economic colleges' teaching staff. Their use is caused by the rapid digitalization of the educational sphere and is aimed at the introduction of new or improvement of existing technologies for organizing educational activities, the ultimate goal of which is to improve the quality of educational services.

Innovative technologies, along with traditional ones, allow significantly expanding the potential of education in Ukraine and effectively implementing the concept of lifelong learning into the domestic educational space. They give the student the opportunity to choose an individual educational trajectory depending on his/her lifestyle, location and work, interest in studying in the relevant specialty, in a particular educational institution in Ukraine or abroad, and so on.

The purpose of the article is to substantiate the types of innovative educational technologies that can be used for successful developing legal competence of economic colleges' pedagogical staff in the system of adult education. 